\title{
Value Added Analysis of Agroindustry Supply Chain Passion Syrup in North Sumatera Province
}

\author{
Kimberly Febrina Kodrat \\ \{kimberly.febrina@gmail.com \} \\ Department Of Industrial Engineering, ITM, North Sumatera, Indonesia
}

\begin{abstract}
Passion fruit (Passifloraceae) is one of the strategic commodities because of its usefulness as a raw material of passion fruit syrup as an agroindustry product that has a rich nutritional value of vitamin $\mathrm{C}$ and beneficial to human health. This research has five elements of supply chain namely farmers, suppliers, extract agroindustry, passion fruit syrup agroindustry, and retailers. The objective of this research is to know the value added by passion fruit after processed into passion fruit syrup, and profit rate, in the processing of passion fruit into passion fruit syrup. The benefit of the research is to provide information and data on the value-added supply chain of passion fruit syrup agroindustry. The research method used was descriptive research with the location of research on the central horticulture of Brastagi and Medan City. The value-added analysis used the Hayami method. The results showed that the value added of passion fruit products at the farm level was $169,680,000 \mathrm{Rp} /$ year and the profit rate of $23.74 \%$, while the added value in the company of passion fruit syrup agroindustry was obtained for $112.500 .000 \mathrm{Rp} / \mathrm{year}$ and the corporate profits rate was $57 \%$.
\end{abstract}

Keywords: Hayami Method, Value Added, Agroindustrial of Passion Fruit Syrup

\section{Introduction}

In this globalization era, there has many emerging new companies in similar industries which will lead to increasingly tight business competition. Business competition today is not just the usual competition, but has reached the competition between the supply chain by providing added value to products and services. Fulfilling customers demand for a product that suits their wants is a key goal in achieving customer satisfaction. Timeliness of deliveries in the production process of a product is one of the main factors in obtaining customer demand and the creation of customer loyalty. This does not escape the concept of supply chain, where the process of procurement, processing and delivery of products to customers is the order of processes and business activities from suppliers (suppliers) to customers.

Industry actors are beginning to realize that to provide cheap, quality and fast products, the internal improvement of a manufacturing company is not enough. These three aspects require the participation of all parties ranging from natural raw material suppliers, factories processing raw materials into semi-finished materials and finished products, transportation companies that ship products to retailers and distribution networks that will deliver products to customers. Awareness of the importance of the role of all parties in creating cheap, quality and fast products created a new concept of supply chain management (SCM) in the 1990s. The concept of supply chain management is able to integrate management of various management 
functions in an inter-organizational relationship forming an integrated and mutually supportive system. The key to effective SCM is to make suppliers "partners" in corporate strategy to meet an ever-changing market [1].

According to Chopra and Meindel (2007), Supply Chain Management is the integration between planning, coordination and control of all business processes and activities in the supply chain to meet consumer needs at a low cost. Supply chain management is the integration of key business processes from end users through genuine suppliers that provide products, services, and information that add value to customers and other stakeholders [2]. The SCM philosophy emphasizes the need for good coordination and collaboration between functions within an organization and between organizations in a supply chain. Supply chain management is generally considered to involve integration, coordination and collaboration within the organization and throughout the supply chain [3]. Supply chain management is an effective business management approach in winning business competition that has been the concern of academics, consultants, practitioners and business managers in recent years [4]. While the supply chain is more emphasized on the flow series and product transformation, the flow of information and finance from the stage of raw materials to the end user [5]. Meanwhile, supply chain management emphasizes efforts to integrate a set of supply chains [6]. According to Lambert (2006) in managing supply chain management there are 3 streams: a) physical flow, b) information flow and c) capital flow[2]. Of the three streams, the flow of information plays an important role in the supply chain. A good supply chain nowadays depends on how the perpetrator manages the flow of information, which can deliver goods faster, which has a higher on time delivery, the movement of goods is fully regulated by information [7].

The theory and practice of SCM implementation has been applied to many international and national scale agroindustry companies (SMEs) and companies engaged in services (hospitals). SCM implementation following the right concept may have an impact on increasing the competitive advantage of the product or the supply chain system built by the company.

The development of agroindustry in Indonesia is an inseparable part of the national industrial policy framework, as can be seen from the large role of agroindustry to non-oil and gas GDP which reached $44.3 \%$ in 2012 . One of the feasibility of industrial developments in Indonesia is the development of natural resource-based industries such as: cocoa, rubber, CPO, food and beverage industry, steel and aluminum upstream, seaweed [8]. The performance of agro-industry in 2013 in the perspective of the realization of the growth of food and beverage processing industry was $4.53 \%$. Agroindustry as one of the pillars of the agribusiness system has a strategic position in the new paradigm as it plays an important role to increase the distribution of income and increase economic growth. Agroindustry, especially small and medium scale, effectively provides employment for unskilled labor[9]. Agroindustry sees several important factors in creating a positive environment for society in general and helps small farmers to survive, where agro-industry also serves as a catalytic factor that can stimulate rural development [10].

Challenges and business problems in the agro-industry sector have also been found in applying supply chain management [6]. The emergence of problems of agro-industry supply chain management is caused by the characteristics of agricultural commodities, namely: a) perishable, b) bulky and c) seasonable and d) quality varies. The perpetrators throughout the supply chain start from the farmers as suppliers, suppliers as suppliers, freight services as third party logistics, manufacturing industries as manufacturers, finished product delivery services, distributors and retailers must pay attention to the main characteristics of the agricultural 
commodity. Indonesia with an agrarian-oriented economic structure should strengthen the agricultural sector through a more robust agricultural development strategy. The development of agribusiness as one of agriculture development strategy is a very important effort to achieve several goals, such as attracting and encouraging new industries in agriculture sector, creating a strong, efficient and flexible economic structure, creating added value, foreign exchange earnings, creating jobs and improving income distribution. The development of agroindustry is one of the efforts to increase the value added of primary products of agricultural commodities which at the same time can change the traditional agricultural system become more advanced.

One of the food crops that is able to support the development of agro-industry is the processing of passion fruit into passion fruit syrup that can last long. This passion fruit syrup is rich in vitamin $\mathrm{C}$ in it is beneficial to the human body as a very potential source.

The development of agro-industries with available raw materials in appropriate quantities and times is a sufficient requirement to produce sustainably. Optimization of added value is achieved in an industrial pattern that integrates directly with family farming and agricultural enterprises. One of Indonesia's development agenda in order to improve people's welfare is through the empowerment of micro small and medium enterprises (UMKM). The entrepreneurial syrup of passion fruit syrup made from passion fruit is mostly found in Brastagi City as horticulture center in North Sumatera Province with production average 2,620 tons / year. From the preliminary survey results, it was found that the supply chain system of passion fruit syrup agroindustry has not been efficient in terms of cost and often inaccurate the amount of fruit supply. There is no good relationship between farmers and collectors due to the uninterrupted flow of information and communication regarding the price and quality of the desired fruit of agro-industry. Information on price and quality standard of fruit that is desired by the sari industry is actually already often delivered to the collecting party but the collectors never informed the farmers. In addition to quality problems, the quantity problem also often occurs that collectors can not supply passion fruit to the sari industry in accordance with the number of orders. The collectors do not really care about it because the collectors are not only supplying fruit to the agro-industry but also out of Brastagi City, traditional markets with much lower quality standards and higher prices than the passion fruit juice industry. So if the passion fruit is not accepted agroindustry extract, the collectors can sell to traditional markets with a larger margin. Observations on the supply chain are conducted to identify a number of problems that often arise in the supply chain and added value to each of the actors in the supply chain of passion fruit products.

\section{Methods}

\subsection{Research Sites}

The data and information gathering activities were conducted in Brastagi City (as passion fruit horticulture center) and as passion fruit extractor and in Medan City as production and marketing center of passion fruit syrup agroindustry.

\subsection{Research Method}

The research was conducted using descriptive observational technique. The number of respondents in this study were 35 people consisting of 6 peasants, 3 collectors, 3 leaders and 
15 employees in the production section and 8 (two) people in the packaging section. The determination of respondents was done purposively with the consideration that the leadership of the company and employees can provide information about the processing of passion fruit syrup as well as data that is accountable and reliable (reliable). Data used in this research consisted of primary data and secondary data. Primary data obtained by way of observation and direct interviews with the leadership of the company and employees of passion fruit agroindustry in Medan City. Data collection used questionnaires and interviews. Value added is a value that states the amount of value given from a production process to the sale value of the product. According to Hayami, the amount of added value because the processing process is obtained from the reduction of raw material costs and other inputs on the value of the products produced, excluding labor. In other words, the added value describes the rewards of capital and management that can be expressed mathematically[9] as follows:

Value added $=\mathrm{f} \quad\{\mathrm{K}, \mathrm{B}, \mathrm{T}, \mathrm{U}, \mathrm{H}, \mathrm{h}, \mathrm{l}\}$ $(1$

Where, $\mathrm{K}$ : production capacity

$\mathrm{B}$ : raw materials used

Q : labor used

$\mathrm{U}$ : labor wage

$\mathrm{H}$ : out put price

$\mathrm{H}$ : raw material price

1: other input values (values and all casualties occurring during the treatment process to add value).

Value-added analysis aims to determine the amount of income earned by each member of the supply chain. The calculation of value added of supply chain members was analyzed following Hayami mathematical model [9] can be seen in Table 1.

Table 1: Calculation of Hayami Valued-Added

\begin{tabular}{clc}
\hline No & \multicolumn{1}{c}{ Variable } & Value \\
\hline Output, Input and Price & $(1)$ \\
1 & Output (ltr) & $(2)$ \\
2 & Raw Material (Kg) & $(3)$ \\
3 & Direct Laborers (HOK) & $(4)=(1) /(2)$ \\
4 & Conversion Factor & $(5)=(3) /(2)$ \\
5 & Coefficient of Direct Laborer (HOK/ltr/ month) & $(6)$ \\
6 & Output Price (Rp/ltr/ Month) & $(7)$ \\
7 & Laborer Wages (Rp/HOK) & $(8)$ \\
Receipts and Profit & $(9)$ \\
8 & Raw Material price (Rp/ltr) & $(10)=(4) \times(6)$ \\
9 & Other input price (Rp/ltr) & $(11 \mathrm{a})=(10)-(8)-(9)$ \\
10 & Output value (Rp/ltr) & $(11 \mathrm{~b})=(11 \mathrm{a}) /(10) \times(100) \%$ \\
$11 \mathrm{a}$ & Value-Added (Rp/ltr) & $(12 \mathrm{a})=(5) \times(7)$ \\
$11 \mathrm{~b}$ & Valued-Added Ratio (\%) & $(12 \mathrm{~b})=(12 \mathrm{a}) /(11 \mathrm{a}) \times 100 \%$ \\
$12 \mathrm{a}$ & Direct Labor Income (Rp/bln) & $(13 \mathrm{a})=(11 \mathrm{a})-(12 \mathrm{a})$ \\
$12 \mathrm{~b}$ & The share of Direct Labor $(\%)$ & $(13 \mathrm{~b})=(13 \mathrm{a}) / 10 \times 100 \%$ \\
$13 \mathrm{a}$ & Profit (Rp/bln) & $(14)=(10)-(8)$ \\
$13 \mathrm{~b}$ & Profit Rate (\%) & $(14 \mathrm{a})=(12 \mathrm{a}) /(14) \times 100$ \\
Reply Service owner of production factors & $(14 \mathrm{~b})=(9) /(14) \times 100 \%$ \\
14 & Margin (Rp/bln) & $(14 \mathrm{c})=(13 \mathrm{a}) /(14) \times 100 \%$ \\
$\mathrm{a}$ & Direct Labor Income (\%) & \\
$\mathrm{b}$ & Other Input Contribution $(\%)$ & \\
$\mathrm{c}$ & Company Profits (\%) &
\end{tabular}


Source: [9]

\section{Result And Discussion}

\subsection{Production of Passion Fruit Syrup}

Agroindustry of passion syrup located In Medan City amounted to 7 units which are in the production process use semi-modern technology. The production of passion fruit syrup at passion fruit agro-industry company is conducted from passion fruit sorting process. Passion fruit is used as passion fruit syrup is a fruit that is half cooked, with the intention that at the time of grinding produce lots of water and vitamin $\mathrm{C}$ content more. The next process is to sanctify and cut fruit. Fruit that has been cut, then removed the contents of fruit, and then done milling to be used as essence juice and last cooked with the condition of sterile and hygienic cooking container so that the extract produced is not stale and durable. The process of making passion fruit syrup graphically can be seen in Figure 1.

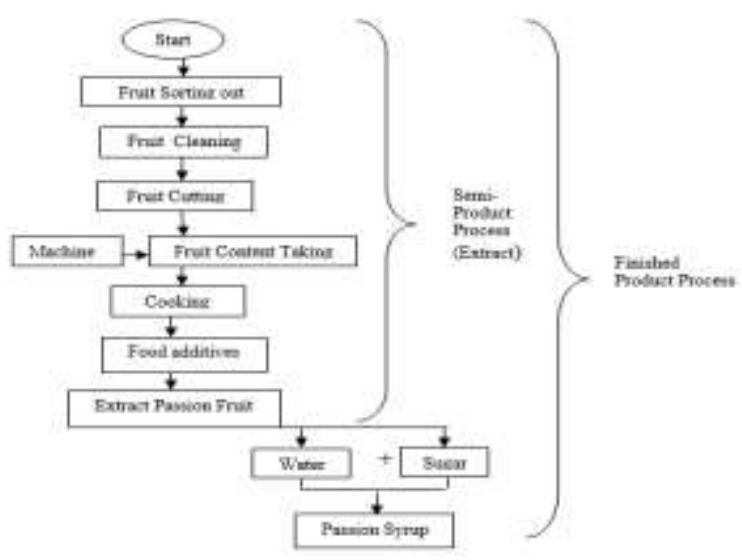

Fig. 1. Stages of passion fruit Production Process

To produce passion fruit syrup, the supply of passion fruit is needed continuously from Brastagi. Passion fruit and passion fruit juice factory is located in Brastagi City. In carrying out the production process of passion fruit syrup, the passion fruit syrup factory located in Medan City got the supply of passionate juice from Brastagi City. Each of the capacity of passion fruit syrup agroindustry can be seen in Table 2 .

Table 2. Capacity of Passion Fruit Production

\begin{tabular}{llc}
\hline No & Name of Agroindustry & Capacity dozen / Year) \\
\hline 1 & Dewi & 15.000 \\
2 & Gundaling & 15.000 \\
3 & Brastagi & 16.000 \\
4 & GK & 16.000 \\
5 & Sarang Tawon & 16.000 \\
6 & Pohon Pinang & 15.000 \\
7 & Piramid Unta & 16.000 \\
\hline
\end{tabular}




\begin{tabular}{llc}
\hline No & Name of Agroindustry & Capacity dozen / Year) \\
\hline & Total & 109.000
\end{tabular}

As a whole, total capacity of agroindustry factory of passion fruit in North Sumatera province is 109.000 dozen/year. The above condition is assumed that the average requirement of passion fruit for 1 agroindustry extract in 1 day is 5 ton. The average working day in 1 month is 24 working days and the fruit that can be supplied in 1 year maximum is 6 months (due to seasonal influence), and the amount of agroindustry in Brastagi City is 3 unit only. Means that fruit can be supplied to 3 agroindustry extract is equal to $=3$ units $x 5$ tons $\times 24$ days $\mathrm{x} 6$ months $=2,160$ tons $/$ year. When compared with the average fruit production in Table 13 (average fruit production / $\mathrm{yr}=2,623$ tons / yr) above, the need for passion fruit is not a problem (in sufficient condition). The fruit that can be absorbed by agroindustry is $82.34 \%$ of the total production of passion fruit per / yr. Passion fruit of 2,160 tons / year will be channeled to 7 units of syrup agroindustry in Medan, which can be converted to 540,000 liter sari / yr $=270,000$ liters of syrup / yr ( 1 liter of syrup $=0.5$ liter juice and 1 liter sari $=4$ $\mathrm{kg}$ of fruit). By looking at this condition, the supply of passion fruit is sufficient.

Based on the data from Table 12 above, to fulfill the capacity of the passengers agroindustry plant of 109,000 ls / yr, the need for passion fruit is 654,000 liter extract / $\mathrm{yr}=$ $2,616,000 \mathrm{~kg}$ passion fruit $(2,616$ tons of fruit). While the average annual fruit production in Karo Regency averaged 2,622.8 tons / year.

\subsection{Added Value Analysis}

Agricultural commodities receive treatment such as processing, preservation, and removal to add usefulness or generate added value. There are two ways to calculate the added value: a) by calculating the added value during the processing and b) calculating the added value during the marketing process. The added value is the difference between the commodities that get treatment at a certain stage and the value of the victims used during the process. The purpose of added value is to measure the rewards received by the system actors and the employment opportunities that commodity systems can create. Or in other words value-added analysis aims to determine the amount of income earned by each member of the supply chain. Calculation of added value in this research that is on farmer, and passion syrup agroindustry.

\subsubsection{Value Added Analysis of Farmers}

Agrified agricultural commodities can motivate farmers to take appropriate measures. On the way from producer to final consumer, agricultural commodities receive treatments such as processing, preservation and removal to add usefulness or add value. Farmers who produce fresh fruit harvest and deliver their fruit to the collectors. Farmers whose land location is far from the market (where the collectors), the harvest will be picked up by the collectors, while the location of the land close to the market, the harvest is transported by the farmers to the market. After the sorting process is completed the passion fruit is packed in burlap sacks to weigh $50 \mathrm{~kg}$ and stored in storage warehouse for ready to be sent to agroindustry extract and partly sold to Brastagi traditional market and out of town of Brastagi. Furthermore the passion fruit is ready to be distributed to every agroindustry sari and also the market both located in the area Brastagi and outside Brastagi. The effectiveness of delivery becomes important, because with the delivery of good quality passion fruit that is sent to keep fresh and nutrient 
content in it is not damaged. For that it takes a short distribution chain, so the possibility of damage to fruit is also getting smaller.

Basically, every farmer has the same level of productivity. The similarity of farmer productivity level occurs because of similarity in using technology, production facilities, and cultivation techniques. While the differentiating factor between one farmer and another is the purchase price to the farmer level by the collectors and other traders. The analysis of value added to the farmers for the time span done during one planting period that is for eight months. The existing farmers obtain production facilities in the form of seeds, fertilizers and pesticides as well as capital at the beginning of planting mass each. The value-added analysis of farmers is related to the number of seeds, other additives such as fertilizers, sacks and ropes and the number of passion fruit produced in each period. The calculation of added value of the members of the farmer supply chain can be seen in Table 3. Each monthly farmer can produce passion fruit of $400 \mathrm{~kg}$ and for 8 months can produce 3.2 tons / year of passion fruit. The selling price of passion fruit at the farmers' level is $\mathrm{Rp} 4000 / \mathrm{kg}$. The calculation of farmer added value is shown in Table 3.

Table 3: Calculation of Value-Added of Farmers

\begin{tabular}{|c|c|c|}
\hline No & Output, input and Price Variables & Value \\
\hline \multicolumn{3}{|c|}{ Output, Input and Price } \\
\hline 1 & Output (kg/month) & 12.000 \\
\hline 2 & Raw Material (kg/month) & 3.000 \\
\hline 3 & Direct Labor (hour/ month) & 12.480 \\
\hline 4 & Conversion Factor & 4 \\
\hline 5 & $\begin{array}{l}\text { Coefficient of direct labor }(\mathrm{HOK} / \mathrm{kg} / \text { month } \\
\text { ton) }\end{array}$ & 4,16 \\
\hline 6 & Output price $(\mathrm{Rp} /$ month & 48.000 .000 \\
\hline 7 & Labor wage (Rp/month) & 30.000 .000 \\
\hline \multicolumn{3}{|c|}{ Acceptance and Profit } \\
\hline 8 & Raw Material price $(\mathrm{Rp} / \mathrm{Kg} /$ month $)$ & 3.000 .000 \\
\hline 9 & Other input price $(\mathrm{Rp} / \mathrm{Kg})$ (fertilizer, sacks) & \\
\hline a & Fertilizers & 15.000 .000 \\
\hline $\mathrm{b}$ & Sacks & 3.600 .000 \\
\hline $\mathrm{c}$ & Rope & 720.000 \\
\hline 10 & Output value (Rp/month) & 192.000 .000 \\
\hline \multirow[t]{2}{*}{$11 \mathrm{a}$} & Value-Added (Rp/month) & 169.680 .000 \\
\hline & Value-Added (Rp/Kg) & \\
\hline $11 \mathrm{~b}$ & Ratio of Value-Added & $88,37 \%$ \\
\hline $12 \mathrm{a}$ & Direct Labor Income (Rp/month) & 124.800 .000 \\
\hline $12 \mathrm{~b}$ & Stock of Direct Labor (\%) & $73,55 \%$ \\
\hline $13 \mathrm{a}$ & Profit (Rp/month) & 44.880 .000 \\
\hline $13 b$ & Profit rate $(\%)$ & $23,77 \%$ \\
\hline \multicolumn{3}{|c|}{ Service of production factor owner } \\
\hline 14 & $\operatorname{Margin}(\mathrm{Rp} / \mathrm{bln})$ & 189.000 .000 \\
\hline $\mathrm{a}$ & Direct Labor Income (\%) & $66,03 \%$ \\
\hline $\mathrm{b}$ & Other input contribution $(\%)$ & $10,22 \%$ \\
\hline $\mathrm{c}$ & Farmers' profit $(\%)$ & $23,74 \%$ \\
\hline
\end{tabular}

Based on the calculation of farmers' value added, the added value ratio is $88.37 \%$ with a profit rate of $23.77 \%$. Low value added ratios can be attributed to low land productivity due to climate problems, soil conditions and watering conditions (Up 2003). This passion fruit 
cultivation area is not specifically used to plant passion fruit, but there are also other types of plants where soil nutrients are also not fully obtainable for the passion fruit.

\subsubsection{Agro Industry Value Added Analysis}

The value added analysis examined in this research is value added analysis on passion fruit syrup agroindustry, which in this case is taken one of agroindustry which has high performance value that is in PT. Sarang Tawon. The calculation of value added analysis of supply chain of passion fruit syrup agroindustry is based on the Hayami model formula contained in Table 1 and calculation result of value added analysis of passion fruit syrup agroindustry can be detailed in Table 4.

Table 4: Calculation of Agroindustry Value added

\begin{tabular}{clr}
\hline No & \multicolumn{1}{c}{ Variable } & \multicolumn{1}{c}{ Value } \\
\hline Output, Input and Price & \\
1 & Output (liter/month) & 12.500 \\
2 & Raw Material (Kg/month) & 25.000 \\
3 & Direct Labor (hour/month) & 3.120 \\
4 & Conversion factor & 0,5 \\
5 & Coefficient of direct labor (HOK/l) & 0,1248 \\
6 & Output price (Rp/liter/month) & 625.000 .000 \\
7 & Labor wage (Rp/month) & 45.000 .000 \\
Acceptance and Profit & \\
8 & Raw material price (Rp/Kg/month) & \\
9 & Other input price (Rp/Kg) (sugar, water, etc) & 75.000 .000 \\
10 & Output value (Rp/month) & 312.500 .000 \\
$11 \mathrm{a}$ & Value Added (Rp/month) & 112.500 .000 \\
& $\quad$ Nilai tambah (Rp/Kg) & \\
$11 \mathrm{~b}$ & Value Added ratio & 36 \\
$12 \mathrm{a}$ & Direct Labor Income (Rp/month) & 5.616 .000 \\
$12 \mathrm{~b}$ & Stock of Direct Labor (\%) & 5 \\
$13 \mathrm{a}$ & Profit (Rp/month) & 106.884 .000 \\
$13 \mathrm{~b}$ & Profit rate (\%) & 34,202 \\
Service fee for production factor owner & \\
14 & Margin (Rp/month) & 3 \\
$\mathrm{a}$ & Direct Labor Income (\%) \\
b & Other Input Contribution (\%) \\
c & Company Profit (\%) & 487.500 .000 \\
\hline
\end{tabular}

Agroindustry section is a member of supply chain of passion agro industry which is responsible to process passion fruit into passion fruit syrup.

Based on the calculation of value added processing section (factory), the ratio of value added 36 and profit rate obtained is $34.2 \%$. This added value ratio is low, which can be affected by the low conversion factor due to the quality of human resources. Factor conversion of raw materials into low products such as the high production waste produced and the low productivity of the factory. Improved value-added parts processing can be done by increasing the productivity of factories and labor supported revitalization of machinery and improvement of quality of human resources. The amount of value added in the processing part occurs because of the large number of additional inputs and processes on the main raw material. This 
is in accordance with Setiawan that the increase in value added can occur due to the introduction of input or increase in the value of prices or processes[11].

\section{Conclusion}

The results showed that the value added OF farmers level is $\mathrm{Rp} 169.680 .000$ with ratio $88.37 \%$ and value added agroindustry of passion fruit syrup product Rp. 112,500,000 / month with $36 \%$ added value ratio.

\section{Suggestions}

The company is advised to continue making efficiency especially in terms of cost and the use of raw materials in the processing of raw materials in order to further enlarge the value added of the resulting product.

\section{Reference}

[1] J. Heizer and B. Render, Operations Management, 7th Editio. New Jersey: Pearson Education, Inc., 2005.

[2] Douglas Lambert, Supply Chain Management: Processes, Partnerships, Performance. Processes, Partnerships, Performance, 4th Editio. Supply Chain Management Institute, 2014.

[3] Stank, P. Theodore, S. B. Keller, P. J, and Daugherty, "Benefits Of Interfirm Coordination In Food Industry Supply Chains. Journal of Business Logistics," Blackwell Publ. Ltd, vol. 12, no. 2, p. $21,2001$.

[4] W. P. Wong and K. Y. Wong, "Supply chain performance measurement system using DEA Modeling," Ind. Manag. Data Syst., vol. 107, no. 3, pp. 361-381, 2007.

[5] R. Handfield and E. L. Nichols, Supply Chain Redesign: Transforming Supply Chains Into Integrated Value Systems. 2002.

[6] V. der Vorst, Performance Measurement in Agrifood Supply Chain Networks: An Overview. Springer Science Business Media, 2006.

[7] I Nyoman Pujawan, Supply Chain Management. Surabaya: Penerbit Guna Widya, 2010.

[8] Dirjen Agroindustri, Agroindustri. Jakarta, 2011.

[9] Hayami and Kikuchi, Rural Economic Dilemma. Jakarta: Yayasan Obor Indonesia, 1987.

[10] D. Giovannucci, "Fixing the Leaky Bucket: Why Agribusiness Matters.In Sustainability of Agricultural Systems in Transition,” Madison WI Am. Soc. Agron. Journal., vol. 5, no. 1, 2001.

[11] S. S. Alim, "Studi Peningkatan Kinerja Manajemen Rantai Pasok Sayuran Dataran Tinggi DI Jawa Barat," J. Nas. AGRITECH, vol. 31, no. 1, 2011.

[1] J. Heizer and B. Render, Operations Management, 7th Editio. New Jersey: Pearson Education, Inc., 2005.

[2] Douglas Lambert, Supply Chain Management: Processes, Partnerships, Performance. Processes, Partnerships, Performance, 4th Editio. Supply Chain Management Institute, 2014.

[3] Stank, P. Theodore, S. B. Keller, P. J, and Daugherty, "Benefits Of Interfirm Coordination In Food Industry Supply Chains. Journal of Business Logistics," Blackwell Publ. Ltd, vol. 12, no. 2, p. 21, 2001.

[4] W. P. Wong and K. Y. Wong, "Supply chain performance measurement system using DEA Modeling," Ind. Manag. Data Syst., vol. 107, no. 3, pp. 361-381, 2007.

[5] R. Handfield and E. L. Nichols, Supply Chain Redesign: Transforming Supply Chains Into 
Integrated Value Systems. 2002.

[6] V. der Vorst, Performance Measurement in Agrifood Supply Chain Networks: An Overview. Springer Science Business Media, 2006.

[7] I Nyoman Pujawan, Supply Chain Management. Surabaya: Penerbit Guna Widya, 2010.

[8] Dirjen Agroindustri, Agroindustri. Jakarta, 2011.

[9] Hayami and Kikuchi, Rural Economic Dilemma. Jakarta: Yayasan Obor Indonesia, 1987.

[10] D. Giovannucci, "Fixing the Leaky Bucket: Why Agribusiness Matters.In Sustainability of Agricultural Systems in Transition," Madison WI Am. Soc. Agron. Journal., vol. 5, no. 1, 2001.

[11] S. S. Alim, "Studi Peningkatan Kinerja Manajemen Rantai Pasok Sayuran Dataran Tinggi DI Jawa Barat," J. Nas. AGRITECH, vol. 31, no. 1, 2011. 